\title{
STRATEGI INTEGRATED MARKETING COMMUNICATION PRODUK THE RED GINGER AL-GHOZALI DI TAMBAK DALAM BARU SURABAYA
}

\author{
Nur Faizah ${ }^{1}$, Sokhi Huda ${ }^{2}$ \\ ${ }^{1,2}$ Universitas Islam Negeri Sunan Ampel Surabaya \\ 1Fnur2367@gmail.com, 22sokhi.huda@ uinsby.ac.id
}

\begin{tabular}{l}
\hline Article Info \\
\hline Article history: \\
Received 5 Agustus 2019 \\
Accepted 7 September 2019 \\
Published 5 Oktober 2019 \\
\hline
\end{tabular}

Keyword:

Home Industry, Integrated Marketing Communications, Bauran Pemasaran.

\section{Abstract}

This study examines the Integrated Marketing Communications (IMC) strategy carried out by Ustadh Al-Ghozali in marketing the red ginger products. IMC strategy plays an important role in the advancement and development of the Home industry. The purpose of this study was to identify the IMC strategy proposed by Al-Ghozali in marketing the red ginger products and to teach this research using a qualitative-descriptive approach with a Marketing Mix theory perspective. The results of this study describe that the IMC strategy carried out by Al-Ghozali includes two stages, namely planning and implementation. In these two stages he employs a strategy of advertising, direct marketing, direct promotion, personal selling, and public relations. The factors that support the success of the IMC strategy are the role of social media and the involvement of resellers. IMC strategy is implemented optimally. Although there are several constrained aspects, there are quite a lot of consumers, especially those in the shop who have collaborated.

Penelitian ini mengkaji strategi Integrated Marketing Communications (IMC) yang dilakukan oleh Ustadh Al-Ghozali dalam pemasaran produk the red ginger. Strategi IMC memegang peranan penting dalam kemajuan dan perkembangan Home industry. Tujuan penelitian ini adalah mengidentifikasi strategi IMC yang dicanangkan oleh AlGhozali dalam pemasaran produk the red ginger serta mengeta Penelitian ini menggunakan pendekatan kualitatif-deskriptif dengan perspektif teori Marketing Mix (Bauran Pemasaran). Hasil penelitian ini mendeskripsikan, bahwa strategi IMC dilakukan oleh Al-Ghozali meliputi dua tahap, yaitu perencanaan dan pelaksanaan. Dalam dua tahap ini dia menggunakan strategi periklanan, pemasaran langsung, promosi langsung, penjualan personal, dan hubungan masyarakat. Faktor-faktor yang menunjang keberhasilan strategi IMC tersebut adalah peran media sosial dan keterlibatan para reseller. Strategi IMC dijalankan secara optimal. Walaupun ada beberapa aspek yang terkendala tetapi cukup banyak pihak konsumen, khususnnya mereka yang ada di warung yang menjalin kerjasama.

Copyright () 2019 Jurnal Ilmu Komunikasi

\section{Editorial Office:}

Program Studi Ilmu Komunikasi, Fakultas Dakwah dan Komunikasi, UIN Sunan Ampel Surabaya. Jl. Ahmad Yani 117 Surabaya, Jawa Timur, Indonesia.

Email: jurnalilkom@uinsby.ac.id 


\section{Pendahuluan}

Pada saat ini, perusahaan-perusahaan besar maupun kecil cenderung mengeluarkan biaya yang cukup banyak untuk melakukan promosi demi mempertahankan produk dan penguatan merek. Selain itu, demi meningkatkan angka penjualan, perusahaan gencar melakukan promosi melalui periklanan maupun alat-alat komunikasi pemasaran lainnya seperti humas, pemasaran langsung, penjualan personal, dan promosi penjualan dalam pemasaran produknya. Untuk hal itu, pendekatan baru dibutuhkan, di mana alat-alat komunikasi pemasaran dapat berjalan efektif dan terintregasi. Salah satunya adalah komunikasi pemasaran terpadu atau Integreted Marketing Commaaunication (IMC). IMC merupakan kegiatan yang berupaya memadukan periklanan dengan alat-alat komunikasi pemasaran lainnya seperti humas, pemasaran langsung, dan promosi penjualan dapat berfungsi secara bersama-sama.

Kegiatan IMC ini mengacu kepada komunikasi pemasaran modern. Strategi ini memfasilitasi proses pertukaran dan pengembangan hubungan dengan konsumen melalui observasi secara cermat terhadap kebutuhan dan keinginan konsumen. Observasi ini dilanjutkan dengan pengembangan produk yang memuaskan kebutuhan konsumen dan menawarkan produk tersebut pada harga tertentu serta diterapkan oleh industri atau penjual sesuai dengan kebutuhan konsumen dan pesaingnya. Hal ini dilakukan agar dapat menghasilkan respon yang diinginkan oleh pasar sasaran. Karena itu, industri

\footnotetext{
${ }^{1}$ Morissan, Periklanan: Komunikasi Pemasaran Terpadu (Jakarta: Kencana Prenada Media Group, 2010), 5.
}

menggunakan konsep IMC yang merupakan gabungan antara beberapa bentuk kegiatan pemasaran yang saling berkaitan dalam upaya memasarkan produk yang dijual dengan tujuan utama peningkatan angka penjualan industri. ${ }^{1}$

Dengan adanya kegiatan Integrated Marketing Communication ini, diharapkan dapat membantu sebuah klub sepak bola untuk memperoleh dana yang dibutuhkan dalam mengarungi sebuah kompetisi yang sedang dijalani. Sebelum penerapan kegiatan IMC, para pemasar atau industri perlu mempertimbangkan berbagai aspek mulai dari aspek ekonomi, sosial, budaya, kebijakan public, dan teknologi, termasuk kondisi pasar persaingan, peraturan serta norma dan etika yang berlaku, sehingga aktivitas komunikasi dalam pemasaran ini akan membuat pesan-pesan tentang produk atau brand menjadi lebih relevan, kreatif serta lebih etis. Oleh karena itu, sebelum merencanakan komunikasi pemasaran, suatu industri perlu mengidentifikasi konsumennya, sasaran, serta proses keputusan mereka.

Komunikasi pemasaran terpadu adalah kegiatan yang berupaya memadukan antara periklanan dengan alat-alat komunikasi pemasaran lainnya seperti humas, pemasaran langsung, promosi penjualan serta event sponsorship untuk bisa bekerja bersamasama menurut ahli. ${ }^{2}$

Berdasarkan konsep komunikasi pemasaran terpadu, perusahaan secara seksama memadukan dan mengkoordinasi semua bauran pemasaran untuk menyampaikan

2 Kotler dan Amstrong, Prinsip-Prinsip Pemasaran (Jakarta: Erlangga 2012), 138. 
pesan yang jelas, konsisten, dan berpengaruh kuat. Komunikasi pemasaran terpadu membentuk identitas merek yang kuat dengan mengikat bersama serta memperkuat citra dan pesan yang ingin disampaikan perusahaan. Selain itu, komunikasi pemasaran terpadu yang dilakukan dapat menghasilkan konsistensi komunikasi yang lebih baik, anggaran komunikasi yang lebih fektif dan dampak penjualan yang lebih besar. Dalam konsep ini perusahaan harus bisa mengkoordinasikan alat-alat komunikasi pemasaran agar dapat bekerja bersamasama. Saling mendukung satu sama lain sehingga bisa saling melengkapi dalam mencapai target audiens yang diinginkan.

Sementara Sistaningrum mengungkapkan arti promosi adalah suatu upaya aatau kegiatan perusahaan dalam mempengaruhi "konsumen aktual maupun "konsumen potensial" agar mereka mau melakukan pembelian terhadap produk yang ditawarkan, saat ini atau dimasa yang akan datang. Konsumen aktual adalah konsumen yang langsung membeli produk yang ditawarkan pada saat atau sesaat setelah promosi produk tersebut dilancarkan perusahaan. Dan konsumen potensial adalah konsumen yang berminat melakukan pembelian terhadap produk yang ditawarkan perusahaan di masa yang akan datang. Promosi penjualan adalah merupakan kegiatan perusahaan untuk menjajakan produk yang dipasarkan sedemikian rupa sehingga konsumen akan mudah melihatnya dan bahkan dengan cara penempatan dan pengaturan tertentu maka produk tersebut akan menarik perhatian konsumen. Promosi penjualan sangat responsif karena mampu menciptakan respon audien terhadap perusahaan.

Tujuan promosi penjualan sangat beraneka ragam, yakni merangsang permintaan, meningkatkan hasrat konsumen untuk mencoba produk, membentuk good will, meningkatkan pembelian konsumen, juga dapat mendorong konsumen untuk membeli lebih banyak serta meminimimkan perilaku berganti-ganti merek, atau mendorong konsumen untuk mencoba produk baru. Tujuan lainnya juga dapat berupa usaha untuk mendorong pembelian ulang produk, dapat menarik pelanggan baru, mempengaruhi pelanggannya untuk mencoba produk baru, menyerang aktivitas promosi pesaing.

Promosi penjualan bertujuan untuk merangsang tanggapan pembeli yang cepat (quick buying response) yang antara lain adalah perlombaan, pemberian hadiah, kombinasi penawaran, kupon, dan potongan harga untuk konsumen.

The Red Ginger adalah produk industri rumahan yang memproduksi minuman terapi yang mempunyai banyak khasiat dan dapat menyembuhkan berbagai penyakit. The Red ginger diproduksi dari jahe merah pilihan. The Red Ginger diolah mejadi minuman serbuk. Di taman dalam lahan Pesantren Alam Bumi al-Qur'an Wonosalam Jombang. The Red ginger diproduksi secara alami dan islami dibacakan al-Qur'an 30 juz sebanyak 99 kali dalam 8 bulan, yakni selama proses penyemaian, pertumbuhan hingga proses produksi.

Pendapatan per tahun Al-Ghozali dapat dilihat pada tabel di bawah ini. 
Tabel 1. Pendapatan Per Tahun Al-Ghozali

\begin{tabular}{|l|l|}
\hline Tahun & Pendapatan \\
\hline 2015 & Rp. 25.000 .000 .00 \\
\hline 2016 & Rp. 90.000 .000 .00 \\
\hline 2017 & Rp. 20.000 .000 .00 \\
\hline 2018 & Rp. 98.000 .000 .00 \\
\hline
\end{tabular}

Pada tahun 2016 pendapatan Al-Ghozali mengalami penurunan. Pada tahun tersebut dia memproduksi sedikit the red ginger karena terbentur renovasi yang ada di pesantren alam Bumi al-Qur'an sebagai tempat utama produksi.

Industri rumahan sendiri saat ini sangat berkembang pesat karena tuntutan ekonomi dan mnyempitnya lapangan pekerjaan. Banyak yang lebih memilih untuk membuka usaha dibidang yang diminati dan dikuasai. komunikasi pemasaran terpadu Al-Ghozali ditujukan untuk memelihara produk The Red Ginger agar menarik perhatian masyarakat yang telah dikemas secara sistematis.

\section{Metode Penelitian}

Penelitian ini menggunakan pendekatan kualitatif-deskriptif. Jenis deskriptif ini menguraikan data yang diperoleh secara mendalam. Jenis penelitian ini bertujuan untuk menggambarkan objek penelitian secara lebih detail mengenai suatu gejala atau fenomena. ${ }^{3}$

Penelitian ini menggunakan tipe studi kasus. Studi kasus merupakan penelitian yang komprehensif mengenai berbagai aspek seorang individu, suatu kelompok, suatu organisasi (komunitas), suatu program,

\footnotetext{
3 Bambang Prasetyo dan Lina Miftahul Jannah, Metode Penelitian Kuantitatif (Jakarta: PT Raja Grafindo, 2005), 45.

4 Sulaksana Uyung, Integrated Marketing Communications (Yogyakarta: Pustaka Pelajar, 2003), 30 .
}

atau suatu situasi sosial. Studi kasus merupakan bentuk penelitian tentang suatu masalah yang memiliki sifat kekhususan (particularity), dapat dilakukan baik dengan pendekatan kualitatif maupun kuantitatif, dengan sasaran perorangan (individual) maupun kelompok, bahkan masyarakat luas.

Penelitian ini menggunakan teknik pengumpulan data sebagaimana dijelaskan oleh Jamesh Mc. Millian dan Saly Schumacer dalam Research in Education: A Conceptual Introduction yang menyebutkan empat multimetode dalam penelitian kualitatif, yaitu (1) observasi partisipan; (2) wawancara mendalam; (3) studi dokumen dan artefak, (4) teknik pelengkap.

\section{Tinjauan Pustaka}

\section{Integrated Marketing Communications}

Integrated Marketing Communications (IMC) adalah konsep perencanaan komunikasi pemasaran yang mengakui nilai tambah rencana komprehensif yang mengkaji peran strategi masing-masing bentuk komunikasi. Misalnya, iklan, direct response, promosi penjualan dan humas dan memadukannya untuk meraih kejelasan, konsistensi dan dampak komunikasi maksimal melalui pengintegrasian pesan. ${ }^{4}$

IMC adalah suatu scape yang menantang dan informasi internal (perusahaan) sampai dengan sistem pengambilan keputusan konsumen. Termasuk di dalamnya pesan dan citra produk yang dipresentasikan oleh perusahaan kepada konsumen potensil maupun stakeholder. ${ }^{5}$ Definisi lain mengenai

${ }^{5}$ Philip Kotler, Principles of Marketing, terj. Bob Sabran. Prinsip-prinsip Pemasaran, Jilid 1 (Jakarta: Penerbit Erlangga. 2008), 8. 
komunikasi pemasaran adalah kegiatan komunikasi yang dilakukan oleh pembeli dan penjual yang merupakan kegiatan yang membantu dalam pengambilan keputusan di bidang pemasaran serta mengarahkan pertukaran agar lebih memuaskan dengan cara menyadarakan semua pihak untuk berbuat lebih baik.

Dalam kajian ini teori yang digunakan adalah teori IMC yang diperkenalkan oleh Don E. Schultz. IMC adalah sebuah konsep dari perencanaan komunikasi pemasaran yang memperkenalkan nilai tambah dari rencana komprehensif yang mengevaluasi peran strategis berbagai disiplin komunikasi, misalnya periklanan umum, respons langsung, sales promotion, dan public relation, serta mengombinasikan disiplin-disiplin ilmu ini untuk memberikan penjelasan, konsistensi, dan dampak komunikasi yang maksimal. Schultz mengemukakan bahwa:

"IMC merupakan konsep perencanaan komunikasi pemasaran yang menghargai pentingnya nilai tambah dari sebuah perencanaan yang komprehensif yang digunakan untuk mengevaluasi peranperan strategi dari berbagai disiplin komunikasi contohnya periklanan secara umum, tanggapan langsung, promosi penjualan, dan kehumasan, dan menggabungkan semua disiplin tersebut untuk menyajikan kejelasan, konsistensi, dan dampak komunikasi yang maksismal." 6

Terdapat dua ide pokok mengenai Teori IMC, yaitu:

a. Komunikasi pemasaran yang bersifat one-voice. Maksudnya adalah walaupun

6 Totok Amin Soefijanto, Integreted Marketing Communication: Marketing Komunikasi di Indonesia (Jakarta: Gramedia Pustaka Utama, 2012), 9 . elemen komunikasi pemasaran yang digunakan berbeda- beda dalam meraih konsumen, namun semua itu harus dapat dikoordinasi dengan cara yang tepat oleh berbagai organisasi dan agensi yang bekerja pada elemen-elemen yang berbeda tersebut.

b. Komunikasi yang berintegrasi; komunikasi di sini tidak hanya bertujuan untuk meningkatkan brand awareness (pencitraan jasa yang baik) saja, namun juga harus dapat menimbulkan hasil penjualan yang baik.

IMC adalah proses yang melibatkan manajemen dan pengorganisasian semua divisi perusahaan dalam menganalisis, merencanakan, melaksanakan, dan mengendalikan semua elemen komunikasi pemasaran, media, pesan dan alat promosi yang berfokus pada target konsumen terpilih untuk mendapatkan peningkatan penjualan dan komunikasi pemasaran dalam mencapai tujuan komunikasi pemasaran produk yang telah ditentukan oleh perusahaan. Dalam pengertian yang paling sederhana, IMC dapat didefinisikan sebagai proses pengelolaan integrasi semua kegiatan komunikasi pemasaran kepada konsumen yang dituju untuk mencapai peningkatan ukuitas merek. ${ }^{7}$

Adapun ciri-ciri IMC antara lain adalah: a. Mempengaruhi Perilaku. Tujuan IMC adalah untuk mempengaruhi perilaku khalayak sasarannya. Hal ini berarti komunikasi pemasaran harus melakukan lebih dari sekedar mempengaruhi kesadaran merek atau "memperbaiki" perilaku

7 David Pickton and Amanda Broderick, Integrated Marketing Communication (Essex: Pearson Education, 2005), 26. 
konsumen terhadap merek. Sebaliknya kesuksesan IMC membutuhkan usahausaha komunikasi yang diarahkan kepada peningkatan beberaoa bentuk respon dari perilaku konsumen.

b. Berawal dari pelanggan dan calon pelanggan. Konsep prosesnya diawali dengan dari pelanggan atau calon pelanggan, kemudian berbalik pada komunikator merek untuk menentukan metode yang paling tepat dan efektif dalam mengembangkan program komunikasi persuasi.

c. Menggunakan seluruh bentuk kontak, artinya IMC menggunakan seluruh bentuk komunikasi dan seluruh "kontak" yang menghubungkan merek atau perusahaan dengan pelanggan mereka, sebagai jalur penyampai pesan yang potensial.

d. Menciptakan sinergi. Dalam definisi IMC terkandung kebutuhan akan sinergi (keseimbangan). Semua elemen komunikasi (iklan, tempat pembelian, promosi penjualan, event, dan lain-lain) harus berbicara dengan satu suara, koordinasi merupakan hal yang amat penting untuk menghasilkan citra merek yang kuat dan utuh, serta dapat membuat konsumen melakukan aksi.

Tujuh tahap komunikasi pemasaran yang menjadi dasar Teori IMC adalah (1) klarifikasi dan segmentasi pelanggan dari Bank data, (2) menentukan titik kontak dengan konsumen, (3) menetapkan sasaran dan strategi komunikasi, (4) menentukan dan memetakan jejaring merek, (5) menentukan sasaran pemasaran, (6) meramu beberapa teknik komunikasi pemasaran yang paling sesuai, (7) memilih taktik komunikasi pemasaran.

8 Totok Amin Soefijanto, Integreted Marketing Communication: Marketing Komunikasi
Secara lebih terperinci lagi, Gurau menyebutkan beberapa faktor yang mempengaruhi tumbuhnya IMC yaitu:

Berkembangnya fragmentasi pasar, kian banyak kegiatan pemasaran yang memanfaatkan hubungan baik dengan konsumen (relationship marketing), dan pemasaran langsung (direct marketing). Kemajuan teknologi komunikasi dan informasi, dan apliklasi basis data. Makin terfragmentasinya pemirsa media, tumpang tindih (multiplicity) dan jenuhnya saluran media. $^{8}$

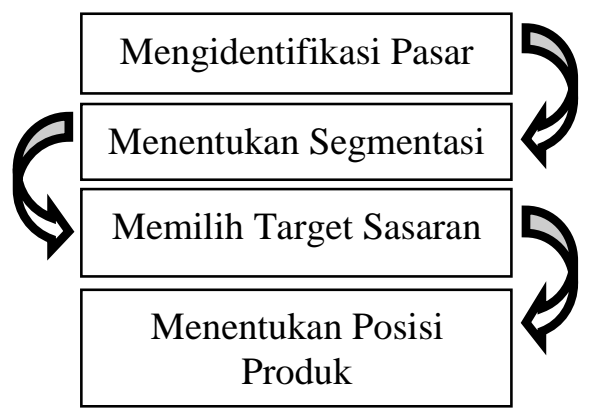

Gambar 1. Proses Strategi IMC

Identifikasi pasar mencakup kegiatan untuk mengelompokkan konsumen yang memiliki gaya hidup, kebutuhan dan kesukaan yang sama. Proses identifikasi pasar dilakukan sebelum melakukan segmentasi pasar. Hal ini dilakukan untuk meminimalisasi kesalahan dalam penetapan strategi pemasaran.

IMC ini hanya membahas satu elemen dari bauran pemasaran, yaitu promosi. Sebelum pelaksanaan IMC, pemasar perlu mengombinasikan terlebih dahulu bauran pemasaran, yaitu produk, harga, distribusi, dan promosi. Bagaimanapun juga, promosi harus terpadu secara sinergis dengan ketiga elemen lainnya, karena sebesar apapun

di Indonesia (Jakarta: Gramedia Pustaka Utama, 2012), 8 . 
biaya yang dikeluarkan untuk promosi, tidak akan sukses apabila produknya berkualitas rendah, harganya tidak sesuai, atau cakupan distribusinya terbatas sehingga sulit ditemukan oleh konsumen.

\section{Strategi Pemasaran}

Strategi merupakan rencana cermat dan sistematis mengenai kegiatan mencapai sasaran khusus. Oleh Lawrence R. Jauch dan William F. Glueck, strategi diartikan sebagai rencana yang disatukan, menyeluruh, dan terpadu yang mengaitkan keunggulan strategi perusahaan dengan tantangan lingkungan yang dirancang untuk memastikan bahwa tujuan utama perusahaan dapat dicapai melalui pelaksanaan yang tepat oleh perusahaan.

Strategi ini terbagi menjadi tiga aktivitas utama yaitu perencanaan, pelaksanaan dan evaluasi program komunikasi pemasaran terpadu. Dalam perencanaan akan dilakukan analisis situasi di sekitar perusahaan dan produk, identifikasi khalayak dan sasaran, penentuan tujuan komunikasi pemasaran, penetapan anggaran komunikasi pemasaran, dan pengembangan program komunikasi pemasaran terpadu.

\section{Perencanaan Komunikasi Pemasaran}

Komunikasi pemasaran diawali pengembangan perencanaan bauran pemasaran yang merupakan dasar dari perencanaan keseluruhan IMC. Perencanaan IMC terdiri atas langkah-langkah koordinasi pemasaran yang dilakukan oleh perusahaan untuk menyampaikan pesan kepada target (konsumen) dan khalayak luas pada umumnya.

Untuk langkah-langkah pengembangan komunikasi dan promosi yang efektif. komunikator pemasaran harus melakukan hal-hal berikut:

\section{Menganilisis Situasi}

Sebelum menentukan tujuan-tujuan pemasaran yang ingin dicapai, hendaknya perusahaan menganalisis situasi lingkungan yang ada diperusahaan. Analiasis ini menggunakan SWOT yang merupakan singkatan dari Strength (kekuatan perusahaan), Weakness (kelemahan perusahaan), Opportunity (peluang bisnis), dan Threat (hambatan untuk mencapai tujuan)

\section{Mengenali Khalayak Sasaran}

Seorang pemasar perlu mengidentifikasi khalayak sasaran yang mungkin adalah calon pembeli potensial atau para pengguna yang ada sekarang, orang yang membuat keputusan membeli atau orang yang mempengaruhi pembeliaan. Khalayak mungkin adalah para individu, kelompok, publik (masyarakat khusus, atau public umum). Khalayak sasaran akan sangat mempengaruhi keputusan-keputusan pemasar tentang apa yang akan disampaikan, bagaimana hal itu disampaikan, kapan itu disampaikan, di mana itu disampaikan, dan siapa yang menyampaikan.

\section{Menetapkan Tujuan Komuniaksi Pemasaran}

Dalam hal komunikasi pemasaran, komunikasi bertujuan untuk membangkitkan keinginan pada konsumen untuk membeli produk. Tetapi pembelian adalah hasil dari proses panjang pembuatan keputusan konsumen. Komunikator pemasaran perlu mengetahui di posisi mana khalayak sasaran berada dan sampai tahap mana khalayak perlu digerakan.

Penentuan tujuan komunikasi pemasaran terpadu adalah hal fundamental sebelum 
pelaksanaannya. Hal ini bertujuan untuk selalu berada di dalam satu koridor dengan tujuan awal. ${ }^{9}$

\section{Menetapkan Anggaran Komunikasi}

\section{Pemasaran}

Salah satu keputusan tersulit yang dihadapi oleh perusahaan adalah berapa banyak biaya yang harus dikeluarkan untuk kegiatan komunikasi pemasaran. Dalam memutuskan besarnya anggaran komunikasi pemasaran secara keseluruhan, terdapat empat metode yang dapat digunakan, yaitu:

1. Metode yang terjangkau (affordability method): metode yang menetapkan anggaran promosi pada level yang dianggap oleh manajemen mampu dikeluarkan oleh perusahaan.

2. Metode presentase dari penjualan (percentage-of-sales budgeting method), yaitu metode yang menetapkan anggaran promosi pada presentase tertentu dari penjualan sekarang atau yang diperkirakan, atau metode yang menetapkan anggran promosi sebagai presentase dari harga jual per unit.

3. Metode paritas pesaing (competitive parity method): metode yang menetapkan anggaran promosi untuk menandingi anggaran para pesaing.

4. Metode tujuan dan tugas (objective and task method): metode yang menetapkan promosi dengan (1) mendefinisikan tujuan khusus, (2) menentukan tugastugas yang harus dilakukan untuk mencapai tujuan tersebut, dan (3) memperkirakan biaya untuk melakukan tugas-tugas tersebut menjadi anggaran promosi yang diusulakan.

9 Philip Kotler dan Gray Amstrong, DasarDasar Pemasaran, Jilid 2 (Jakarta: Indeks, 2004), 610.

\section{Perkembangan IMC di Indonesia}

Melihat perusahaan-perusahaan di dalam negeri umumnya baru menjalankan IMC pada level taktis (tahap satu), baru sebatas menggabungkan semua elemen promosional secara sinergis untuk menciptakan one voice. Kondisi ini memang sangat terkait dengan bagaimana perusahaan tersebut memahami IMC. Repotnya, di Indonesia banyak perusahaan keluarga yang masih berpikir secara tradisional.

Dalam implementasi IMC, peran top management sangatlah penting. IMC pada dasarnya adalah aplikasi komunikasi secara strategis yang melingkupi keseluruhan aktivitas bisnis. Dari komunikasi yang dulunya terkotak-kotak dan terlokalisasi di setiap bagian atau departemen berubah menjadi komunikasi terintegrasi yang melibatkan peran serta seluruh significant stakeholder guna mendukung tujuan bisnis dan pemasaran. "Situasi ini jelas membutuhkan pengambilan keputusan pada level strategis atau top management atas berbagai investasi yang dibutuhkan," menurut Etaswara. ${ }^{10}$ Investasi dalam IMC sangat mahal dan berjangka waktu panjang. Investasi ini tidak hanya meliputi investasi pada teknologi komunikasi dan informasi, namun juga investasi pada proses pembangunan. IMC itu sendiri dan SDM di dalamnya. Selain itu, transformasi organisasi dari struktur tradisional menjadi "The IMC Company" bukanlah pekerjaaan mudah. Konflik antar bagian, antar departemen atau antar profesi sangat berpotensi mewarnai perubahan ini.

10 Setia Budhi Wilardjo, "Integrated Marketing Communications", Value Added 5, no. 2 (Maret-Agustus 2009): 5. 
Maka, peran top management sangat krusial dan strategis. Pendekatan outside-in juga mutlak dibutuhkan. "Untuk menjadi The IMC Company yang sesungguhnya, informasi dari situasi eksternal yang unpredictable ini, terutama umpan balik dari pelanggan harus menjadi dasar dalam mengelola perusahaan guna mencapai tujuan bisnis dan pemasaran," lanjut Etaswara.

Sulit dipungkiri, bahwa teknologi digital telah membuat masyarakat konsumen menjadi semakin melek media dan melek teknologi. Akibatnya, cita rasa konsumen menjadi semakin beragam dan personal. Fragementasi konsumen ini akhirnya menyebabkan terciptanya diversifikasi media komunikasi.

Jawaban atas semua masalah ini adalah IMC (IMC), suatu proses bisnis yang menggunakan perencanaan, eksekusi, koordinasi, dan pengukuran dari semua aktivitas komunikasi yang ditujukan kepada konsumen, karyawan dan pihak-pihak terkait lainnya. Semua komunikasi bekerja bersama-sama sebagai kekuatan terpadu, bukan terpisah, untuk mendapatkan tingkat return (ROI) terbaik serta merek yang kuat. Sejak kemunculannya pada awal dekade 1990, konsep IMC sendiri telah menjadi topik yang hangat di dunia marketing. Berbagai perusahaan mulai melirik terobosanterobosan baru dalam berkomunikasi secara interaktif dengan pelanggan. Komunikasi yang interaktif inilah yang akan membuat mereka mampu menjalin relationship yang kuat dengan pelanggan. ${ }^{11}$

Hasil penelitian menunjukkan bahwa prospek IMC ke depan menunjukkan tren

\footnotetext{
11 Setia Budhi Wilardjo, "Integrated Marketing, 12 .
}

yang positif. Hal ini ditunjukkan dengan meningkatnya kepercayaan terhadap IMC sebagai strategi komunikasi pemasaran yang efektif dan efisien di era informasi dewasa ini, serta tingginya kepercayaan terhadap peningkatan anggaran IMC ke depan, minimal untuk tiga tahun mendatang.

IMC yang dimaksudkan di Indonesia sejauh ini umumnya masih sekedar dalam artian one voice atau upaya penciptaan brand image dengan mengintegrasikan secara strategis dan sinergis semua alat promosional. Sehingga, tren positif atas IMC ke depan harus dimaknai secara hatihati. Artinya, yang meningkat masih diseputar anggaran perusahaan untuk belanja iklan, anggaran untuk programprogram customer relationship melalui event marketing, anggaran publisitas melalui upaya public relations, sampai anggaran pembelian teknologi komunikasi dan informasi untuk mendukung program loyalitas pelanggan. Hal ini selaras dengan pemahaman IMC yang hanya diartikan secara eksternal-operasional.

IMC sepertinya bukan barang baru. Tapi perhatian terhadap konsep ini justru semakin mengemuka belakangan ini. Ledakan media yang demikian dahsyat seperti kemunculan media televisi baru, misalnya menjadi salah satu tolok ukur mengapa IMC bakal berjaya di masa mendatang. Belum lagi media luar ruang seperti billboard semakin lama semakin Menjamur. Ditambah dengan internet dan mobile content, maka semakin lengkaplah peran IMC di masa mendatang. ${ }^{12}$

\footnotetext{
${ }^{12}$ Buchari Alma, Strategi Pemasaran (Bandung: Alfabeta, 2003), 37.
} 
Sesuai dengan namanya, maka IMC berupaya menggabungkan berbagai tools dalam komunikasi untuk dijadikan sebuah strategi yang memiliki fundamental kuat. Dengan semakin kompleksnya media komunikasi, maka tugas marketer di masa depan adalah bagaimana menjaga semua kompleksitas ini agar tetap fokus pada sasaran yang diharapkan.

Untuk menggabungkan semua elemenelemen promosi, ada beberapa hal yang harus diperhatikan dalam pelaksanaan IMC agar sukses ${ }^{13}$ sebagai berikut:

\section{Peran yang Kuat dari Top Management}

IMC sebenarnya membutuhkan campur tangan dari top management karena menyangkut integrasi yang demikian besar, bahkan dapat melibatkan beberapa divisi di luar marketing. Ketiadaan campur tangan dari orang-orang setingkat general manager atau direksi dapat membuat konflik. Sebagai contoh, bagian marketing telah membuat program promosi untuk para nasabahnya. Namun demikian, bagian customer service ternyata tidak memperoleh informasi tentang program ini. Akibatnya, ketika ada nasabah yang bertanya, bagian customer service atau call center tidak dapat menjawab pertanyaan nasabah. Kalaupun top management tidak turun tangan dalam operasional, paling tidak urusannya adalah melakukan proses pembagian tugas.

\section{Fokus pada Satu Sasaran}

Dalam perbandingan dengan pendekatan tradisional yang cenderung mengarah pada banyak hal karena tidak ada koordinasi, IMC berfokus pada satu sasaran dengan banyak pendekatan komunikasi. Ujung dari
IMC, tentu saja, adalah perubahan perilaku konsumen. Namun perubahan perilaku ini harus direncanakan sejak awal pada saat integrasi channels of communication yang ada.

\section{Didorong Kebutuhan Konsumen}

IMC berfokus pada kebutuhan konsumen. Artinya, strategi IMC dibangun di atas suara konsumen. Hal ini berbeda dengan pendekatan tradisional. Sekalipun pendekatan tradisional juga menggali data konsumen lewat riset, tetapi pada saat memformulasikan strategi komunikasi marketer cenderung mendominasi kebutuhan perusahaan terhadap konsumen. Sebagai contoh, pada saat pemasangan iklan di televisi yang bersifat massal, sebenarnya kita memaksakan semua konsumen menonton iklan kita.

\section{Database}

Dengan fokus pada kebutuhan konsumen secara spesifik, IMC harus memiliki database yang kuat dan mampu menjawab berbagai perubahan dalam perilaku konsumen. Database merupakan pusat kegiatan IMC. Itulah sebabnya IMC secara sekilas seperti aktivitas CRM (Customer Relationship Management) yang juga mengelola database pelanggan. Namun, CRM lebih berfokus pada manajemen pelanggan, sedangkan IMC pada manajemen komunikasinya. Biasanya, IMC memang mendapatkan feedback dari aktivitas CRM karena CRMlah yang melakukan pengelolaan pelanggan. Dari feedback pelanggan ini, IMC kemudian bertugas memformulasikan strategi yang tepat untuk berkomunikasi dengan pelanggan.

\footnotetext{
${ }^{13}$ Buchari Alma, Strategi, 36.
} 
Berteman dengan Teknologi

IMC harus "bekerja sama" dengan teknologi untuk mengatasi kerumitan menggali setiap aspek dari perilaku pelanggan. Teknologi yang membuat marketer mampu secara lebih cepat dan mudah menangkap setiap perilaku pelanggan. Itulah sebabnya perkembangan IMC sering dikaitkan dengan IT seperti internet, di mana pelanggan dapat berinteraksi secara dua arah dengan perusahaan. Oleh karena itu, jangan mengabaikan teknologi, sekalipun belum terlalu penting pada saat sekarang. Pada saat konsumen sudah begitu terkait dengan teknologi, maka IMC juga tidak boleh "gaptek". Sebagai contoh, konsumen sekarang sudah pintar menggunakan handphone, maka strategi IMC juga harus masuk ke kanal-kanal baru seperti handphone ini.

\section{Bukan Proyek Jangka Pendek}

IMC bukanlah proyek jangka pendek. IMC adalah strategi besar yang dibangun oleh perusahaan. Sebagai contoh, bila ada produk baru yang dikeluarkan, perusahaan baru mengintegrasikan beberapa saluran komunikasi. Namun, pada kondisi normal, perusahaan kembali berfokus pada mass advertising. Padahal IMC seharusnya menjadi "grand design" komunikasi yang dibangun oleh perusahaan. Di dalam IMC ada proses evaluasi dan penggalian kebutuhan konsumen yang kemudian dituangkan kembali kedalam strategi ke depan.

\section{Perubahan Organisasi}

Dalam pelaksanaan strategi IMC dengan baik, struktur perusahaan harus lebih mampu mengakomodasi kebutuhan konsumen. Organisasi perusahaan harus mampu menangkap perilaku konsumen, mengelolanya, dan menghasilkan strategi dengan cepat. Untuk hal ini, organisasi yang terhubung dengan baik antardepartemen dibutuhkan. Jika sebuah organisasi terlalu birokratis, maka keputusan menjadi sulit dilakukan dan terlalu lama. Padahal aktivitas kompetitor mungkin sangat gencar. Sasaran organisasi dari IMC, seperti halnya CRM, sebenarnya adalah membentuk budaya customer driven di dalam perusahaan. Aplikasi IMC di banyak perusahaan mengalami kendala karena adanya organisasi bisnis yang kurang sesuai, budaya perusahaan, struktur sampai ke kualitas SDM.

\section{Pengukuran (Measurement)}

Keuntungan dengan adanya IMC adalah pada pengukuran. Dahulu perencanaan advertising, sales promotion dan direct marketing terpisah-pisah sehingga ukuran keberhasilannya sulit diperoleh. Akan tetapi dengan adanya IMC, ukuran keberhasilan dapat dilihat, akibat adanya perencanaan dan kontrol yang lebih adanya perencanaan dan kontrol yang lebih terpusat. Selain itu, pengaruh IMC terhadap perilaku konsumen lebih terpantau dari waktu ke waktu. Hal ini berbeda dengan pendekatan tradisional. Pada saat iklan diluncurkan, evaluasinya dilakukan pada saat itu juga dan bersifat short-time. Dengan adanya IMC sebenarnya marketer lebih mampu melakukan pengukuran. Namun, sayangnya, banyak pihak yang justru melupakan cara untuk mengukur efektivitas strategi IMC ini. Padahal, ukuran keberhasilan tentunya sudah harus dibuat pada saat perencanaan IMC. 


\section{Ciri-ciri Utama IMC (Integrated Marketing Communication)}

Dalam buku Periklanan Promosi Aspek Tambahan Komunikasi Pemasaran Terpadu oleh Shimp ${ }^{14}$, ciri-ciri utama IMC adalah mempengaruhi perilaku. Tujuan IMC adalah mempengaruhi perilaku khalayak sasarannya. Hal ini berarti komunikasi pemasaran harus melakukan lebih dari sekedar mempengaruhi kesadaran merek (brand awareness) atau "memperbaiki" perilaku konsumen terhadap merek. Sebaliknya, kesuksesan IMC membutuhkan usaha-usaha komunikasi yang diarahkan kepada peningkatan beberapa bentuk respons dari perilaku konsumen. Dengan kata lain, tujuannya adalah menggerakkan orang untuk bertindak.

\section{Hasil Penelitiaan dan Pembahasan}

Strategi IMC Ustadh Al-Ghozali dalam Pemasaran the Red Ginger

Integrated Marketing Communication (IMC) merupakan sebuah revolusi atau pengembangan dari komunikasi pemasaran. Konsep IMC lebih berfokus pada satu tujuan dengan penggunaan alat-alat promosi untuk memproduksi efek satu suara yang koheren yang bekerja secara sinergis untuk mengkomunikasikan pesan tertentu. Banyak perusahaan yang saat ini melakukan IMC untuk memadukan dan mengkoordinasikan semua saluran komunikasi untuk menyampaikan pesannya secara jelas, konsisten, dan berpengaruh kuat tentang organisasi dan produk-produknya. IMC, selain digunakan untuk mempertahankan citra merek pada konsumen luas, ia juga digunakan sebagai salah satu strategi untuk menarik minat suatu perusahaan atau investor sponsorship sehingga berdampak pada kerjasama antarkedua belah pihak.

Strategi IMC yang dilakukan Ustadh Al-Ghozali dalam pemasaran produk the red ginger adalah sebagai berikut:

\section{Perencanaan}

Strategi perencanaan ini meliputi empat sub-perencanaan. Sub-perencanaan pertama adalah pemberdayaan santri untuk mengenal dunia bisnis dan melatih soft skill mereka. Sejak awal produksi the red ginger AlGhozali sudah mulai memberdayakan santrinya untuk mengenal dunia bisnis dan untuk melatih soft kill mereka, agar mereka ketika di masyarakat sudah mulai terbekali keterampilan tertentu. Pada saat ini semua orang dituntut kreativitasnya. Oleh karena itulah pada saat ini pemerintah sedang membangun sebuah pemikiran tentang santripreneur.

Sub-perencanaan kedua adalah pemanfaatan jejaring pesantren. Salah satu strategi Al-Ghozali dalam pemasaran the red ginger adalah pemanfaatan pesantren Alam Bumi al-Qur'an untuk memasarkan produk the red ginger. Karena menurut AlGhozali, Provinsi Jawa Timur mempunyai banyak pondok pesantren tetapi yang bergerak dan mempunyai produk sendiri masih sangat minim.

14 Terence A. Shimp, Periklanan Promosi Aspek Tambahan Komunikasi Pemasaran Terpadu, (Jakarta: Erlangga, 2003), 25. 
Sub-perencanaan ketiga adalah analisis situasi. Sebelum penentuan tujuan-tujuan pemasaran yang ingin dicapai, analisis situasi lingkungan memang perlu dilaksanakan. Analisis ini menggunakan SWOT; Strength (kekuatan perusahaan), Weakness (kelemahan perusahaan), Opportunity (peluang bisnis), dan Threat (hambatan untuk mencapai tujuan). ${ }^{15}$ Penjelasannya adalah sebagai berikut:

a. Strength \& Weakness merupakan kekuatan dan kelemahan perusahaan. Kekuatan merupakan faktor pendukung tercapainya tujuan usaha, sedangkan kelemahan perusahaan dapat menjadi penghambat. Ustadh Ghozali sendiri menyadari betul bagaimana kekuatan yang dimilikinya sekarang dan kelemahannya. Faktorfaktor yang menjadi kekuatan Ustadh Al-Ghozali sendiri adalah para reseller karena produk the red ginger sebagian besar berhasil dijual secara online maupun offline oleh para reseller.

b. Opportunity merupakan peluang bisnis yang ada di luar perusahaan. Pertumbuhan atau perubahan kehidupan masyarakat sekitar seringkali memunculkan peluang yang menjanjikan kepada perusahaan yang menangkap peluang tersebut. Pada era sekarang, berbisnis dalam bidang minuman herbal sudah begitu banyak tetapi jika mengolah sistem IMC-nya dengan baik maka akan semakin banyak peluang yang masuk.

c. Threat merupakan berbagai macam hambatan untuk mencapai tujuan. Perkembangan lingkungan bisnis yang kurang menguntungkan misalnya munculnya

${ }^{15}$ Fritz Kleinsteuber dan Siswanto, Strategi Manajemen Pemasaran (Jakarta: Damar Melia Pustaka, 2002), 8. pesaing-pesaing produk dan dalam masalah kemasan karena the red ginger tidak dikemas secara sachet dapat menjadi penghambat perusahaan untuk mencapai tujuan.

Sub-perencanaan ketiga adalah mengenali khalayak sasaran. Dalam identifikasi khalayak sasaran diperlukan analisis segmentasi pasar, penentuan target sasaran, dan pemosisian produk. Al-Ghozali sendiri melakukan pengenalan dan penyaringan terhadap khalayak pasar karena di wilayah Tambak Dalam sendiri manfaat jahe merah ini masih belum dikenal oleh masyarakat.

Setelah pengenalan target sasaran, pemosisian produk dilakukan. Pemosisian ini menunjukkan kekhasan produk berbeda dengan produk-produk pesaingnya. AlGhozali melakukan pemosisian produknya untuk membedakannya dengan produkproduk lainnnya. Aspek yang membedakan the red ginger dengan produk jahe merah lainnya adalah rasa. Hal ini sudah dibuktikan oleh para konsumennya sendiri.

Sub-perencanaan keempat adalah penetapan tujuan komunikasi pemasaran. Dalam hal komunikasi pemasaran, komunikasi bertujuan untuk membangkitkan keinginan pada konsumen untuk membeli produk. Akan tetapi pembelian merupakan hasil dari proses panjang pembuatan keputusan konsumen. Komunikator pemasaran, misalnya resseler, perlu mengetahui di posisi mana khalayak sasaran berada dan sampai tahap mana khalayak perlu digerakkan. ${ }^{16}$ Dalam hal ini perlu adanya sebuah tujuan; diarahkan ke manakah sasaran

16 Kotler dan Amstrong, Dasar-dasar Pemasaran, 610 
yang akan dicapai. Hal ini sebagaimana dalam promosi, khalayak mana yang lebih atau bagaimana cara agar khalayak tertarik dengan produk the red ginger.

Penentuan tujuan komunikasi pemasaran terpadu merupakan hal yang fundamental sebelum pelaksanaannnya. Hal ini bertujuan untuk selalu menjaga konsistensi pelaksanaan komunikasi pemasaran agar selalu berada di dalam satu koridor dengan tujuan awal. Tujuan pemasaran yang dilakukan oleh alGhozali sendiri adalah ingin memanfaatkan hasil dari para santrinya berkebun tersebut dan membuka lapangan pekerjaan sampingan bagi siapa pun yang membutuhkannya.

\section{Pelaksanaan}

Setelah perencanaan komunikasi pemasaran yang matang dan strategis dilaksanakan, perusahaan mengombinasikan konsep pemasaran kepada khalayak secara kolektif dan integratif yang disebut Komunikasi Pemasaran Terpadu (Integrated Marketing Communication). Ada beberpa strategi yang dilakukan dalam pelaksanaan IMC untuk mencapai target melalui reseller, bagaimana meyakinkan konsumen untuk tertarik membeli produk tersebut, yaitu dengan cara mempromosikan the red ginger dengan baik promosi melalui media maupun pemasaran secara langsung.

Al-Ghozali mempromosikan produknya melalui media periklanan. Iklan merupakan penyampaian pesan melalui ruangan yang dibayar oleh pemasang iklan. Iklan merupakan bentuk komunikasi yang sungguh-sungguh merasuk yang mencapai setiap lapisan dan anggota masyarakat.

\footnotetext{
${ }^{17}$ Kotler dan Amstrong, Dasar-dasar, 640.
}

Media-media iklan bermacam-macam; iklan media sosial, televisi, radio, sampai iklan-iklan di surat kabar dan majalah serta poster. Iklan merupakan sebuah alat yang sangat berpengaruh untuk membangkitkan kesadaran kelompok sasaran perusahaan.

Tujuan pemasangan iklan adalah tugas komunikasi tertentu yang harus dilakukan terhadap khalayak sasaran tertentu yang spesifik selama periode tertentu.Tujuan utama pemasangan iklan, yaitu menginformasikan, membujuk, dan mengingatkan. ${ }^{17}$ Dalam beriklan dibutuhkan strategi jitu untuk pemasangan iklan. Strategi pemasanga iklan terdiri dari dua unsur yaitu menciptakan isi pesan yang akan disampaikan dan memilih media yang tepat untuk memasang iklan.

AL-Ghozali mempunyai stategi jitu dalam beriklan melalui media sosial dengan endorsing terhadap para selebgram yang muslim tetapi bukan dari kalangan artis seperi Gus Hadi dari personel Ahbabul Mustofa dan Veve Zulfikar yang memiliki banyak fans dan cukup hits di kalangan anak muda.

Strategi lainnya yang dilakukan oleh Al-Ghozali adalah pemasaran langsung (direct marketing). Strategi ini merupakan bagian dari program komunikasi pemasaran. Pada saat ini tidak dapat diduga, secara psikis masyarakat memiliki kemungkinan berubah sangat cepat. Mereka sangat cepat belajar sehingga membentuk sikap defensive yang kuat. Kognisi mereka perlu diperkuat dan diulang setiap saat. ${ }^{18}$

18 Risky Soemanagara, Strategi Marketing Communication (Bandung: Penerbit Alfabet, 2006), 37. 
Komunikasi dengan calon konsumen atau target yang paling ideal ialah melalui pertemuan langsung. Iklan yang paling baik tidak berbicara 'pasar' tetapi berbicara kepada setiap individu. Pemasaran langsung merupakan teknik 'komunikasi massal' yang paling tepat untuk mendekati sasaran sehingga membuat perusahaan dapat menyampaikan pesan-pesan secara pribadi. Pemasaran langsung membuat perusahaan dapat menentukan segmensegmen sebagaimana yang kita inginkan dan memberikan medium yang efisien dalam penyampaian pesan-pesan kepada pasar. Namun, ada permasalahan yang muncul di saluran distribusi pesan, yaitu ketika pemasar mencoba menemukan daftar-daftar yang tepat untuk kelompok sasaran yang dituju. Al-Ghozali bahkan pernah melakukan pemasaran langsung saat di daerah Tambak Dalam agar orang percaya bahwa the red ginger memang produk dari Ustadh Al-Ghozali sendiri.

Dalam direct marketing Al-Ghozali melakukan dua strategi. Pertama, strategi promosi penjualan personal. Promosi penjualan terdiri dari insentif-insentif jangka pendek. Secara umum, tujuan promosi penjualan adalah menciptakan hubungan, bukan hanya menciptakan penjualan jangka pendek saja. Pada hakikatnya, tujuan promosi penjualan mendorong pembelian, membangun percobaan di antara non-pemakai, dan menjauhkan orang yang sering berganti produk dari pesaing.

Promosi merupakan aktivitas pemasaran yang mengusulkan nilai tambah dari suatu perusahaan untuk mendapatkan nilai yang medorong minat dari khalayk sasaran yang akan dituju. Penjualan personal merupakan komunikasi langsung antara perusahaan dengan calon investor dan calon sponsor untuk memperkenalkan profil perusahaan tersebut. Promosi dan penjualan personal ini yang dilakukan oleh Al-Ghozali lebih condong diberikan ke warung.

Kedua, strategi hubungan masyarakat. Hubungan masyarakat merupakan upaya komunikasi menyeluruh dari suatu perusahaan untuk mempengaruhi presepsi, opini, keyakinan, dan sikap dari berbagai kelompok terhadap perusahaan tersebut. Ustadh Al-Ghozali membangun hubungan komunikasi atau berinteraksi dengan para reseller, konsumen, dan pihak-pihak yang terkait dengan baik. 


\section{Pembahasan}

Penelitian ini menggunakan perspektif teori Marketing Mix yang digunakan dalam usaha menarik konsumen dengan melakukan 4P yang berlaku untuk produk secara umum. Ide pokok mengenai Marketing Mix merupakan bagian dari komunikasi pemasaran terpadu atau Integrated Marketing Communication (IMC), yaitu komunikasi pemasaran yang bersifat one-voice. Al-Ghozali meskipun menggunakan pemasaran dan promosi dengan menggunakan media yang berbeda-beda dalam menarik konsumen tetapi tetap saja semuanya sudah terkonsep dan tertata dengan baik.

Ada empat hasil penelitian yang penting dibahas dalam bagian pembahasan ini. Pertama, product (produk). Produk merupakan apa saja yang dapat ditawarkan untuk mendapatkan perhatian, permintaan, pemakaian, atau konsumsi yang dapat memenuhi keinginan atau kebutuhan. ${ }^{19}$ Produk tidak hanya selalu berupa barang tetapi dapat juga berupa jasa ataupun gabungan dari keduanya (barang dan jasa). Produk merupakan kombinasi barang dan jasa yang di tawarkan perusahaan kepada pasar sasaran. Produk tidak hanya meliputi unit fisiknya saja tetapi juga kemasan, garansi, merek, dan pelayanan saat menjual.

Kedua, price (harga). Penetapan harga merupakan suatu hal penting. Perusahaan akan melakukan hal ini dengan penuh pertimbangan karena penetapan harga akan dapat mempengaruhi pendapatan total dan biaya. Harga merupakan faktor utama penentu posisi dan harus diputuskan sesuai dengan kondisi pasar sasaran, bauran ragam produk, dan pelayanan, serta persaingan.

Ketiga, place (tempat). Tempat atau lokasi yang strategis akan menjadi salah satu keuntungan bagi perusahaan karena mudah terjangkau oleh konsumen, namun sekaligus juga menjadikan biaya rental atau investasi tempat menjadi semakin mahal. Tingginya biaya lokasi tersebut dapat diganti dengan mengurangi biaya pemasaran, sebaliknya lokasi yang kurang strategis akan membutuhkan biaya pemasaran lebih mahal untuk menarik konsumen agar berkunjung. Dekorasi dan desain sering menjadi daya tarik tersendiri bagi para target konsumen. Kondisi bangunan juga menjadi persyaratan yang memberikan kenyamanan.

Keempat, promotion (promosi). Promosi merupakan suatu aktivitas dan materi yang dalam aplikasinya menggunakan teknik, di bawah pengendalian penjual/produsen, yang dapat mengkomunikasikan informasi persuasif yang menarik tentang produk yang ditawarkan oleh penjual/produsen, baik secara langsung maupun melalui pihak yang dapat mempengaruhi pembelian. Tujuan kegiatan promosi, antara lain, adalah (1) mengidentifikasi dan menarik konsumen baru, (2) mengkomunikasikan produk baru, (3) meningkatkan jumlah konsumen untuk produk yang telah dikenal secara luas, (4) menginformasikan kepada konsumen tentang peningkatan kualitas produk, (5) mengajak konsumen untuk mendatangi tempat penjualan produk, dan

${ }^{19}$ Murti Sumarni dan John Soeprihanto, Pengantar Bisnis (Dasar-dasar Ekonomi Perusahaan), Edisi ke5 (Yogyakarta: Liberty, 2010), 274. 
(6) memotivasi konsumen agar memilih atau membeli suatu produk.

Untuk keperluan promosi, Ustadh AlGhozali menetapkan dua strategi. Strategi pertama adalah menentukan produk dan harga. Sejak awal produksi the red ginger Ustadh Ghozali sudah menetapkan harga dengan berbagai packaging yang beda dan berat bersihya pun berbeda. Sedang strategi kedua adalah penentuan lokasi pemasaran yang strategis. Pemilihan lokasi sangat menentukan dalam usaha menarik khalayak sasaran untuk membeli produk the red ginger, karena terdapat $40 \%$ warung dan toko di desa Tambak Dalam Baru. Dalam strategi kedua ini Al-Ghozali menentukan lang-langkah sebagai berikut:

1. Awal pemasaran dan promosi menggunakan sistem door to door. Awal produksi the red ginger Al-Ghozali sempat menggunakan sistem pemasaran dari rumah ke rumah sekaligus untuk berkomuikasi langsung dengan konsumen. Hal inilah yang membuat the red ginger langsung melejit. Bahkan sebagian besar resselernya juga dari kalangan warga Tambak Dalam Baru.

2. Promosi melalui media sosial Facebook dan Instagram. Pada era sekarang media sosial dianggap penting oleh sebagian besar masyarakat, ini tidak terkecuali oleh Al-Ghozali. Kehadiran media sosial sangat berpengaruh bagi Al-Ghozali dalam usaha membangun citra (image) yang lebih baik lagi, sehubungan dengan peran konten media sosial yang dapat diakses dengan mudah oleh masyarakat luas.

Al-Ghozali memanfaatkan keberadaan media sosial untuk mempromosikan produknya seperti Facebook dan Instgram dengan menggunakan jasa selebgram muslim muslimah yang cukup hits di kalangan anak muda. Hasil dari strategi IMC tersebut menunjukkan adanya keberhasilan yang cukup memuaskan. Hal ini dapat dilihat dari jumlah permintaaan konsumen lewat media sosial.

\section{Kesimpulan}

1. Strategi Integrated marketing communication Al-Ghozali dalam pemasaran produk the red ginger terdapat dua tahapan yaitu pertama, perencanaan dengan langkah-langkah yaitu: (a) menganalisis situasi yang berkembang di pasar untuk mengetahui kebutuhan masyarakat, (b) mengenali khalayak sasaran, dengan mengetahui latar belakang dan tujuan kondisi pasar, mempermudah AlGhozali dalam pemasaran yang lebih baik produk the red ginger. Kedua, pelaksanaan strategi Integrated Marketing Communication yang dilakukan AlGhozali yaitu bagaimana hubungan antara Al-Ghozali dan para reseller serta konsumen lain agar menjalin kerjasama untuk mencapai tujuan dengan baik pula, yakni memasarkan produk the red ginger sesuai dengan target.

2. Strategi komunikasi pemasaran terpadu dilakukan oleh Al-Ghozali dengan menggabungkan beberapa unsur promosi pemasaran yang dilakukan secara optimal untuk mencapai target yang maksimal. Promosi dan penjualan personal, merupakan alat yang menaikkan nilai jual dan membantu personal selling untuk menginformasikan segala informasi tentang produk the red ginger kepada para konsumen. Serta menguatkan agar 
persebaya lebih dikenal di kalangan luas termasuk kalangan konsumen. Hubungan masyarakat dilakukan terhadap seluruh yang terlibat dengan Ghozali untuk membina hubungan baik dan menjaga kepercayaan yang diberikan oleh pihak konsumen untuk menjaga citra dari produk tersebut.

3. Faktor penunjang keberhasilan produk the red ginger ini adalah melalui para resseller dan media sosial juga berperan dalam menunjang keberhasilan tersebut. Al-Ghozali menggunakan media sosial Facebook dan Instagram untuk mempromosikan produknya tersebut. Al-Ghozali memanfaatkan secara optimal fasilitas yang dimilikinya itu.

4. Faktor yang menghambat keberhasilan tersebut adalah sudah banyak persaingan minuman herbal khususnya jahe merah dan masalah packaging karena konsumen yang di warung membutuhkn packaging dalam bentuk sachet. Kondisi transisi tersebut membuat sedikit ketertarikan pihak konsumen warung.

\section{Daftar Pustaka}

Alma, Buchari. Strategi Pemasaran. Bandung: Alfabeta, 2003.

Kleinsteuber, Fritz dan Siswanto, Strategi Manajemen Pemasaran. Jakarta: Damar Melia Pustaka, 2002.

Kotler, Philip dan Amstrong, Gray. PrinsipPrinsip Pemasaran. Jakarta: Erlangga 2012.

Kotler, Philip dan Amstrong, Gray. DasarDasar Pemasaran, Jilid 2. Jakarta: Indeks, 2004.
Kotler, Philip. Principles of Marketing. Terj. Bob Sabran. Prinsip-Prinsip Pemasaran, Jilid 1. Jakarta: Penerbit Erlangga. 2008.

Morissan. Periklanan: Komunikasi Pemasaran Terpadu. Jakarta: Kencana Prenada Media Group, 2010.

Pickton, David and Broderick, Amanda. Integrated Marketing Communication. Essex: Pearson Education, 2005.

Prasetyo, Bambang dan Jannah, Lina Miftahul. Metode Penelitian Kuantitatif. Jakarta: PT Raja Grafindo, 2005.

Shimp, Terence A. Periklanan Promosi Aspek Tambahan Komunikasi Pemasaran Terpadu. Jakarta: Erlangga, 2003.

Soefijanto, Totok Amin. Integreted Marketing Communication: Marketing Komunikasi di Indonesia. Jakarta: Gramedia Pustaka Utama, 2012.

Soefijanto, Totok Amin. Integreted Marketing Communication: Marketing Komunikasi di Indonesia. Jakarta: Gramedia Pustaka Utama, 2012.

Soemanagara, Risky. Strategi Marketing Communication. Bandung: Penerbit Alfabet, 2006.

Sumarni, Murti dan Soeprihanto, John. Pengantar Bisnis (Dasar-dasar Ekonomi Perusahaan), Edisi ke-5. Yogyakarta: Liberty, 2010.

Uyung, Sulaksana. Integrated Marketing Communications. Yogyakarta: Pustaka Pelajar, 2003.

Wilardjo, Setia Budhi. "Integrated Marketing Communications", Value Added 5, no. 2 (Maret-Agustus 2009): 5. 